Etnográfica

Revista do Centro em Rede de Investigação em

Antropologia

vol. 25 (1) | 2021

Vol. 25 (1)

\title{
(Dis)trusted outsiders: conducting ethnographic research on prison settings
}

Gerir a (des) confiança: a realização de pesquisa etnográfica em contextos prisionais

\section{Sílvia Gomes and Rafaela Granja}

\section{(2) OpenEdition}

Journals

Electronic version

URL: https://journals.openedition.org/etnografica/8678

DOI: 10.4000/etnografica.8678

ISSN: 2182-2891

\section{Publisher}

Centro em Rede de Investigação em Antropologia

\section{Printed version}

Number of pages: 5-22

ISSN: 0873-6561

Electronic reference

Sílvia Gomes and Rafaela Granja, "(Dis)trusted outsiders: conducting ethnographic research on prison settings", Etnográfica [Online], vol. 25 (1) | 2021, Online since 05 March 2021, connection on 28 January 2022. URL: http://journals.openedition.org/etnografica/8678 ; DOI: https://doi.org/10.4000/ etnografica.8678

Etnográfica is licensed under a Creative Commons Attribution-NonCommercial 4.0 International License. 


\section{(Dis)trusted outsiders:}

\section{conducting ethnographic research} on prison settings

\section{Sílvia Gomes and Rafaela Granja}

This article aims to contribute to the growing body of literature that critically reflects on the practical, ethical and relational challenges raised by conducting research in prison. Basing our work on three different studies developed in Portuguese prison settings, we develop an intersectional understanding of building (dis) trust in prison settings by reflecting upon researchers' characteristics and relational dynamics with people in the field, whether they are professionals or prisoners.

KEYWORDS: prison, ethnographic research, (dis)trust, challenges.

Gerir a (des)confiança: a realização de pesquisa etnográfica em contextos prisionais - Este artigo pretende contribuir para o crescente corpo de literatura que reflete criticamente sobre os desafios práticos, éticos e relacionais na realização de investigação científica em contexto prisional. Baseado em três estudos desenvolvidos pelas autoras em contextos prisionais portugueses, neste artigo desenvolvemos uma compreensão interseccional da construção da (des)confiança em ambientes prisionais, refletindo sobre as características das investigadoras e as dinâmicas relacionais com as pessoas no campo, sejam elas profissionais ou reclusos/as.

PALAVRAS-CHAVE: prisão, investigação etnográfica, (des)confiança, desafios.

GOMES, Sílvia (silvia.gomes@ics.uminho.pt) - Centro Interdisciplinar de Ciências Sociais, Universidade do Minho, Portugal; Florida State University, USA.

GRANJA, Rafaela (r.granja@ics.uminho.pt) - Centro de Estudos de Comunicação e Sociedade, Universidade do Minho, Portugal. 


\section{INTRODUCTION}

"Aren't you afraid?" is the most frequent question we hear after the sentence "I conduct research on prison settings." Such a dialogue became so frequent in conversations with people who are unfamiliar with prison dynamics that we felt the need to interrogate it from a sociological standpoint. What kinds of challenges emerge while developing research in prison? To what extent do our personal characteristics - as young and female - intersect with and influence the conducting of research in prison settings? What are the changes we go through during and after such intense periods in prisons?

Since the middle of the $20^{\text {th }}$ century, prison research has played a central role in fostering understanding about life in prison and about the organization of criminal jurisdictions (Clemmer 1940; Sykes 1958; Giallombardo 1966; Cohen and Taylor 1972; Heffernan 1972; Jacobs 1977; Toch 1977). However, as Wacquant (2002) noticed, there has been an "eclipse" of the tradition of prison ethnography in countries such as the United States, which face hyper-incarceration. Nonetheless, this decrease in ethnographic research is not common to criminal jurisdictions around the world (Drake, Earle and Sloan 2015). As Manuela Cunha (2014a) shows in a review of the ethnography of prisons, in Europe and Latin America there are several research studies conducted in the prison scenario. By expanding the empirical field to non-US research and including contexts with different legal, penal and social settings, these in-depth studies thus allow for the identification of similarities and disparities that emerge from different milieus (Cunha 2002; Liebling 1999).

Ethnographic prison studies allow for the exploration of the situated meanings attributed to imprisonment and experiences of the several groups that populate those institutions, as well as engaging with the exercise of critically reflecting on the particularities of conducting research in such controlled and securitized contexts (Rhodes 2004; Piacentini 2004; Drake 2012; Crewe 2009, 2014; Jewkes 2014; Liebling 2014; Rowe 2014; Jewkes and Wright 2016). Several researchers working in prisons explicitly described and reflected on the strains and challenges of their ethnographic practice (Giallombardo 1966; Jacobs 1977; Zwerman and Gardner 1986; Jewkes 2012; King 2000; Liebling 1999, 2001; Waldram 2009). Acknowledging the limits of outsider

I Sílvia Gomes (mentioned as SG in this article) would like to thank the Foundation of Science and Technology (FCT, Portuguese Ministry of Science, Technology and Higher Education) for funding this research through a PhD fellowship (ref. SFRH/BD/47010/2008) and continuing to give financial support through a postdoctoral grant (ref. SFRH/BPD/102758/2014). Rafaela Granja (mentioned as RG in this article) would like to thank FCT for funding the PhD research with a fellowship (SFRH/ $\mathrm{BD} / 73214 / 2010)$. Both authors would also like to thank the anonymous reviewers and the editor for the comments and questions which have been decisive in improving the article. Finally, we also thank all participants in these three studies for sharing their stories and experiences with us. 
participation in prison settings, Owen (1998) and Crewe (2006) use the terms "quasi-ethnography" and "ethnographic research methods" to describe their approaches. The use of these terms aims to highlight how complex and challenging fieldworkers' access to prison settings can be (Wacquant 2002; Cunha 2014a). Despite this discussion, and assuming the diverse barriers that can be faced with an ethnographic approach, accounts of ethnographic research in prison settings vary in detail. Therefore, there are gaps remaining in our knowledge of the "subtle and detailed techniques deployed by prison ethnographers in the field and the particular emotional demands associated with this work" (Drake and Harvey 2014: 492).

Taking this into account, Yvonne Jewkes has, therefore, proposed to use autoethnography and emotion as resources in prison research (Jewkes 2012). Anchored in such a proposal, this article aims to contribute to the growing body of literature that critically reflects on the practical, ethical and relational challenges raised by conducting ethnographic research in prison. More particularly, we develop an intersectional understanding of building (dis)trust in prison settings by reflecting upon researchers' characteristics and relational dynamics with people in the field, whether they are professionals or prisoners. By focusing on the Portuguese reality, we aim to disclose how several of these aspects and dynamics, scarcely advanced by national literature (see exceptions in Cunha 1994, 2002) and mostly by international studies, are revealed and gain particular features in national prisons.

\section{OPENING THE BLACK BOX}

Prisons are contexts where dichotomies such as power and vulnerability, control and dependency, security and loss of liberty are continuously assembled and disassembled on a daily basis (Drake 2012). Entering such a context with the aim of conducting research thus constitutes an intense, unpredictable and emotionally-taxing experience (Crewe 2009) that should be taken into consideration as an additional lens to explore prison social life (Jewkes 2012). Doing so implies recognizing the multiple and unforeseen influences of the researchers' social location in terms of gender, social class, ethnicity, and age (Phillips and Earle 2010; Cunha 2014b), acknowledging relational challenges as part of the research process (Rowe 2014) and emphasizing the dynamic character of the process of building trust (Nielsen 2010; Bucerius 2013). Interrogating the position occupied by researchers in prison allows for an exploration of the mutable meanings associated with being human in a highly controlled and securitized custodial environment (see Jewkes and Wright 2016).

While conducting research in criminal justice settings, researchers become embedded in complex and continuously shifting power flows that pose a direct influence on their positioning, perceived role and access to participants and 
prison facilities. In other words, researchers become both infused with power and subject to it (Liebling 2014: 482). Building trust and maintaining rapport in such an environment is, therefore, a challenging task, and becoming an insider, an almost impossible one. However, as noted by Sandra Bucerius (2013) in her ethnographic research with second-generation Muslim immigrants involved in the informal economy in Frankfurt, being perceived as a trusted outsider, instead of an insider, might be a useful position to gain in-depth knowledge and to explore the dynamics of a certain group.

In this article we consider reflexivity as "participant objectivation" (Bourdieu 2003). This implies not only understanding participants' viewpoints and experiences, but also the wider conditions under which knowledge is produced. In other words, it involves an "exploration of this academic unconscious" (Bourdieu 2003: 285) that takes into consideration who we are (as researchers) and how the way we think is shaped by traditions, habits, and shared commonplaces of our own histories and those of our discipline (O'Reilly 2012: 522). Simply put, this implies "turning back on oneself" (Davies 1999: 4), going beyond the practical issues raised by fieldwork, capturing the positioned observer's sense of things (Drake, Earle and Sloan 2015), and outlining the subjective experience of doing research in ways that imply a reflexive engagement with our own identities.

Drawing upon this framework, we thus aim to reflect critically on how our personal and professional characteristics and our strategies to deal with challenges derived from fieldwork intersect with and affect the process of gaining access, establishing trust and maintaining rapport with the several respondents and informants in the prison context. Based on such an approach, our article thus navigates the travels and "troubles" - and the pains and gains (Beyens et al. 2015) - of entering the field. In particular, we engage in the processes of negotiating prisons' simultaneous openness and restriction, managing their formal and informal procedures, getting to know different penitentiary agents and associated roles and powers, taking challenging decisions, ascribing and being ascribed several identities, constructing trust (and dealing with suspicion), and facing reactions from ourselves and from others.

\section{ASSEMBLING PIECES OF A PUZZLE}

Portugal has witnessed a substantial increase in the prison population since 2008. According to the latest data available in World Prison Brief data, the country has a total prison population rate of 126 prisoners per 100,000 inhabitants, which, in the European scenario, positions it as a very punitive country. ${ }^{2}$

2 See World Prison Brief data at < http://www.prisonstudies.org/country/portugal > (last access in May 2020). 
While prison sentences in Portugal tend to be between three and 20 years, in other European countries individuals tend to be convicted to less than three years of imprisonment. Consequently, the average sentencing time in Portugal is three times higher than the European average (31 months, against 11.1 months in Europe). A curious fact is that the rate of entries to penal institutions in Portugal is relatively low (51.9) in comparison with Europe (195.7) and the rate of releases is also low (54,6 in Portugal, and 154.3 in Europe). ${ }^{3}$ This means that in Portugal, although fewer people enter prison, they tend to stay imprisoned for longer periods (Aebi, Tiago and Burkhardt 2016). This tendency partially explains the overpopulation in Portuguese prisons.

The empirical material presented in this article was collected within three different studies developed in Portuguese prison contexts. The first aimed to explore the pathways to prison of ethnically and gender diverse prisoners and their relationship with the criminal justice system (Gomes and Silva 2014; Gomes 2014, 2017, 2018). The second research focused on how prison professionals and prisoners conceive and act upon the re-entry process in the prison context (Gomes 2019). The third aimed to explore the familial and social impact of imprisonment (Granja 2016, 2017, 2018; Granja, Cunha and Machado 2013, 2014). All these studies were conducted individually but we discussed our research experiences with each other throughout the entire duration of fieldwork for the writing of this article.

Although focused on different themes, our studies assemble a complex puzzle. In particular, the three studies discuss interrelated issues about prison social life; they were conducted in Portugal by researchers who share similar characteristics in terms of gender, age, and professional status; and they make use of the same research techniques - such as documental analysis, direct observation, informal conversations and semi-structured interviews. In this sense, we argue that our combined experiences are able to shed light on the ways through which the field is accessed, how the strategies for building trust in relations with participants are constructed, and the forms whereby researchers' characteristics interrelate in a dynamic process, permeated by challenges, opportunities and constraints. To achieve this goal and following what Drake and Harvey (2014) advanced, we've selected significant aspects of our fieldwork experiences and reflected on the most vivid memories and major challenges that we experienced across these various projects in which we have been involved.

Access to prisons in all mentioned studies was formally granted through the Portuguese General Directorate of Reintegration and Prison Services and permitted by the Director of each prison in a schedule suitable for both

3 Rates of entries and releases to penal institutions per 100,000 inhabitants; see data at < https:// wp.unil.ch/space/files/2017/04/SPACE_I_2015_FinalReport_161215_REV 170425.pdf > (last access in May 2020). 
prisional services and researchers. All studies involved fieldwork in male and female Portuguese prisons over a period of six months to one year. No permission for previous incursions in the field and/or continued visiting was obtained. In the following section, we discuss the process of negotiating access in a low-trust environment with prison professionals. Then, the process of managing (dis)trust with prisoners is addressed. In the last section, we use the insights provided by the analysis of our experiences and relationships in prison to reflect upon the challenges associated with conducting ethnographic research in prison settings.

\section{NEGOTIATING ACCESS IN A LOW-TRUST ENVIRONMENT: INTERACTING WITH PROFESSIONALS}

As academic researchers conducting fieldwork in prisons, we tend to be seen as "distrusted outsiders." That is, as external elements that create even more distress in an environment that has its own frenetic and highly defined routines and rhythms. Portuguese prisons have, therefore, put in place formal requirements that must be followed by researchers, namely: (i) obtaining an authorization from the General Directorate of Reintegration and Prison Services to develop fieldwork; (ii) gaining authorization from the Director of each prison to enter a particular setting; (iii) getting professionals' and prisoners' authorization to participate in the study, through signed consent.

Besides these formal requirements for conducting research in a prison setting, such a context also implies the constant management of informal rules - composed of (in)visible social hierarchies and unspoken norms. When gathering information about the prison population, selecting potential interviewees and seeking to understand in detail the bureaucratic intricacies of the penal system, it becomes clear that prison professionals are unavoidable social actors who must be considered. They represent valuable informants who facilitate, inform and provide privileged access to data collection. Taking into consideration their central influence on the development of studies, it is therefore important to understand and critically reflect upon how such professionals perceive and deal with our role as researchers, insofar as this conception largely affects what is said and revealed and, by extension, what is omitted and obstructed (Becker 1994: 54). Although prison professionals - such as prison guards, members of direction boards and/or administrative personnel - are not the focus of all the studies on which this article is based, their perceptions, actions and decisions clearly affect the negotiation of access to infrastructures and to prisoners, as well as the broader relational conditions in which fieldwork occurs.

Our combined experiences show that prison staff's reactions to the conducting of academic studies in prison tend to range from resistance and skepticism to enthusiasm and active engagement with researchers. Among 
those professionals who adopted a resistant posture during fieldwork, it was possible to understand that such a position was related to research fatigue and/or to skepticism about the concrete impact of academic research on prison policies. In particular, prison professionals tended to mention how studies generally focus solely on prisoners, thus bypassing staff experiences and narratives - as Nielsen (2010) also mentioned. On other occasions, staff would react to research aims with disbelief, making jokes that reproduce dominant ideas about criminality, as one prison director who reacted to the presentation of the research topic on familial relationships by saying: "Family? Don't you know that crime runs in their [prisoners] veins? Just go and do your interviews but, look, it would be better to save time and write this" [fieldnotes, RG].

Despite some reactions such as these, other staff members also expressed curiosity about the studies being developed, shared impressions regarding their own professional or personal experience and made themselves available for helping with the whole process. This oscillation between different reactions further complicated the initial and on-going process of negotiating access and turning ourselves into "trusted outsiders." If, at one moment, we might be dealing with someone who vigorously restricts our access to prison infrastructures and participants - by, for instance, implicitly or explicitly discouraging prisoners from participating in an interview -, at the next moment, we might be dealing with someone who offers to help us with a guided visit to certain rooms and/or facilitates contact with prisoners so that the first interaction takes place without unnecessary pressure.

In this negotiation between what might, at a first instance, be seen as contradictory reactions to the role of researchers in prison settings, we outline the influence of two main dimensions: how professionals conceive and deal with researchers' particular characteristics and professional status, and how the theme of research is perceived by these individuals.

Within the first dimension, we argue that one of the characteristics that more clearly influenced how professionals dealt with us concerns our perceived youthfulness and our gendered identities, which played out differently in female and male prisons. In female prisons, being women helped to place us in a position largely distant from a potential threat to prisoners. By contrast, in male prisons, as we were young and female, our presence was generally seen as potentially destabilizing in a hyper-masculinized environment (see Bandyopadhyay 2006). According to prison professionals, such alleged destabilizing effect was, however, not so much related to potential episodes of violence directed toward us but to hypothetical encounters of a romantic character. That is, instead of being seen as potentially helpless women, we were perceived as youthful women whose sensuality should be concealed. Indeed, during one of the first meetings in a male prison where RG conducted fieldwork, the assistant director highlighted the "suitability" of her own 
clothing in such an environment. After commenting on her youthful appearance, she said:

"Interns come in here dressed as if they were going out at night. Does it make sense? Necklines, mini-skirts, heels. Then they have love affairs with prisoners. I have already seen that you are not like that, don't worry. But we have very serious problems in here with this" [fieldnotes, RG].

Even though such a comment was made in a complimentary tone, it was clear enough that it indicated a prevalent attitude towards "controlling" female behavior in a male-dominated setting. Although subtly, the assistant director was somehow prescribing what would be the "appropriate" and "inappropriate" dress code and, by extension, the "appropriate" female attitude in prison: the modest woman who does not dress/express herself in a provocative manner.

Coupled with this gendered identity, the hetero-management of our identity was also linked to our university affiliation and, in particular, to our role as (PhD) students. Our perceived youthfulness, both in terms of biological age but, more importantly, in terms of the role we occupied in the academic hierarchy, placed us in the largely distanced position of a potential threat since we were conceived as naïve young students, relatively passive and devoid of symbolic power. Such a conception, however, changed in one of the prisons where SG was conducting fieldwork when someone discovered she was a university professor and shared this with colleagues. Such information had noticeable effects on the way SG was perceived and treated by professionals. Besides changing how they would address her - instead of Sílvia, as she asked several times to be named, she became Dr. Sílvia or Professor Sílvia -, professionals also became more aware of the potential impact of her work. This therefore gave rise to ambivalent situations: if, on some occasions, it was clear that certain information was being concealed, at other moments professionals and prisoners approached SG with a strong belief that she would be the "right person" with whom to share privileged information and access. For instance, in some situations, permission was granted for access to schools, clinical sectors and disciplinary cells, to validate professionals' findings. This kind of access had never been granted before when SG was perceived as a "mere" (PhD) student. In effect, our combined experiences show how being perceived as a student or as a professor produces different points of access and establishes variable ways of gaining trust, according to the differentiated symbolic power attributed to each one of those positions.

Besides the situation in which professional status interferes with what is said and shown (and not said and not shown), the theme of the study also exerted significant influence on the negotiation of relationships with prison professionals. While prisoners' criminal trajectories or prisoners' familial 
relationships were generally conceived as innocuous themes that do not raise "sensitive issues" about prison life, the focus on the re-entry process tends to be considered as a problematic issue that should not be addressed openly with "distrusted outsiders" like us. At a time when Portuguese prisons are struggling with funding cuts and the number of prisoners is increasing - a growth of $22.5 \%$ in the last five years - there is an unspoken generalized perception that re-entry or social reintegration does not work. As a chief prison guard said, in a defiant tone, in front of several other colleagues:

"Study what? What is it? Have you seen it? Social reintegration is a white elephant! A great white elephant! Everyone talks about it, but no one has ever seen it! [...] So stop doing that, because whoever can actually do something doesn't want to do anything!" [Fieldnotes, SG.]

That kind of strong positions expressed by professionals working in prisons creates complex ethical dilemmas for researchers: on the one hand, it entirely defies the work being conducted and might even cause a sense of resentment on the part of researchers; on the other, it opens the possibility of in-depth conversations with professionals about the reasons behind that opinion. Despite feeling offended by such a defiant statement, SG decided to talk privately with the chief prison guard, in order to clarify the aims of her research. The explanation significantly changed the interaction. The chief prison guard explained how his frustration regarding the topic of social reintegration is based on more than 20 years of service, with different general directors and different prison directors. He expressed his belief that there is nothing that can be done while minimal resources and basic conditions of habitability are still a problem in national prisons. As a result, despite being fostered by an unpleasant situation, this interaction allowed SG to more clearly grasp the particularities of the topic under study.

The initial interactions with members of prison staff clearly show how the ways in which we introduce ourselves, present our research topic and deal with the several reactions it raises are especially relevant to how our status is understood inside prison and, by extension, to the level of access allowed, trust and expectations placed on us. However, such negotiations are not restricted to the initial stage of the fieldwork. Even when fluid relational dynamics with professionals are established, this does not prevent uncomfortable and defiant situations from happening. This clearly outlines that the terms of our presence in the prison and the modes of our participation are unstable and beyond our ability to determine (Rowe 2014), and that we permanently oscillate between the positions of (dis)trusted outsiders. One clear example of such ever-changing dynamics is an episode that happened to SG after two months of fieldwork in the same prison. 
"Since a trusting environment between professionals and researchers was perceived to exist, one day, after finishing an interview, I stopped by the chief guards' office, as I used to do daily before lunch. I placed the digital recorder on the table, along with my notebook, and continued to talk to the prison guards. Suddenly, I looked at the table and realized that the digital recorder was no longer there. I felt panic and became disoriented. The commissioner suggested that I confirm whether I had left the digital recorder in the room where I did the interview and I did so - although I was pretty sure I did not leave it there. Indeed, it was not there. When I returned to the chief guards' office, the commissioner pointed to the floor. The digital recorder was there. In that position, it was quite obvious it had not fallen. I confronted the commissioner, because, realizing that it was a prank, I got nervous and upset. The commissioner then revealed the bottom line to me, by saying that inside a prison one can never be relaxed since no one knows who can enter or leave the offices and sabotage my work. Therefore, I should always be vigilant and not become sloppy" [fieldnotes, SG].

We chose to describe this highly uncomfortable moment because it highlights several interrelated elements that are part of the experience of conducting research in prisons. The first element relates to the pivotal aspect of the relation between trust and secrecy. In an institution where any revelation of information can put someone else in danger, the importance of honoring the protection of information provided to the ethnographer is paramount. As such, this episode shows the constant risk of having the identities and narratives of our participants - to whom we ensure confidentiality and anonymity - revealed while simultaneously dealing with prison professionals. The second interrelated element regards the continuous balance between (de)constructing trust and rapport. As already demonstrated by Jewkes "in the prison context, researchers frequently have to position themselves (physically and ideologically) between officers and prisoners, which can be detrimental to the building of trust and rapport with both sides" (2012: 67). This episode clearly shows such challenging position, by representing a clear reminder, made in a paternalistic tone, that SG should be aware of her standings: as an outsider, she should keep in mind that prisons are "dangerous" places where no one should be trusted - a notion that is well entrenched in prison culture.

Such combined experiences of interacting with professionals rough out the multiple values of (dis)trust that have to do with the dual allegiance of the researcher working in prisons. This dual allegiance is inscribed at different scales: from the department of carceral affairs (that authorizes, or not, access to prisons) to the local prison administration (that decides the terms and forms in which access will occur); from the head of the prison (that prescribes what can and cannot be done) to the prison staff (that manages information to 
conceal and information to share and constantly reminds researchers of their outsider position) and, finally, from the prison staff to the detainees, which is the focus of the following section. In addition, such experiences also underscore the importance of an intersectional understanding of building (dis)trust in prisons by shaping how perceived appearance, gender and professional status play a pivotal role in interacting with professionals in a low-trust environment.

\section{MANAGING (DIS)TRUST: INTERACTING WITH PRISONERS}

In the process of approaching prisoners and conducting interviews, the compounding effects of how our perceived youthfulness, gendered identity, professional occupation and research topic were conceived also played a central role. However, the terms under which such influences occurred are quite different from the process of negotiating access with professionals. In our first contact with potential interviewees we were able to introduce ourselves and to present the aims and purpose of the research. These first moments were characterized by an effort to explain that we had a serious interest in and commitment to hearing their experiences - in the sense of engaged listening, advanced by Forsey (2010) - and understanding their views.

Within this process, our role as social scientists - that is, as individuals detached from the criminal justice system and with an institutional affiliation to a university - played a central role in managing trust and distrust. Nevertheless, in some cases this dimension was made especially difficult because of prisoners' low educational levels. Some prisoners had no idea about the dynamics of academic work and the image of the social scientist seemed odd to them. Therefore, it was especially difficult to make clear why we wanted to talk with them. Questions such as "Who do you work for?" or "Will this be published in the magazines?" punctuated several requests for interviews with both researchers. We were often associated with other professional figures such as social workers, psychologists, lawyers, police officers, journalists, etc. Owing to prisoners' contact with State institutions and, in particular, with the criminal justice system, all these professional categories were more easily interpreted by our interviewees than the social scientist figure. However, they are also professional statutes that prisoners generally do not trust and our association with them therefore raised additional challenges. This led to the need for detailed explanations prior to the interview where the differentiation between our purposes and other professionals' was made clear. In this respect, the best explanation RG found was to say that her aim was to write a book about prisoners' experiences with regard to families. ${ }^{4}$ In the same sense, SG

4 This book was, indeed, published (Granja 2017) and sent to prisoners where fieldwork was conducted in an attempt to make it available to all participants. 
also advanced, particularly with illiterate prisoners, the explanation that the conversation would be used for a school project.

Despite the challenges in explaining the aims and specific purposes of each study, prisoners in general were largely interested in and responsive to our request for participation. Regarding interactions during interviews, we share Alison Liebling's view that "our research participants did not want to be 'subjects' but acted as agents. They participated, made choices, drew us into relationships with them, and involved us in their world" (Liebling 1999: 158). They generally participated actively and sometimes in an enthusiastic manner, responding to questions with deep emotional narratives, describing past and present experiences in great detail, remembering moments with intense joy and/ or anger, laughing and shedding tears of despair. They told us jokes, made us laugh and sometimes almost made us cry. They showed us photos of their loved ones, gave us craftwork they had made and thanked us for the opportunity to talk to someone about their life. In response to their openness, we attempted to adopt the position of "empathic listeners" (Drake and Harvey 2014) ready to absorb each and every story and detail about their experiences. Elliott comments that incarcerated individuals often "benefit from being given the chance to reflect on and talk about their lives with a good listener" (2005: 137). As shown by the following narrative from one of the prisoners interviewed, this kind of response was also present in our fieldwork experiences.

"I really enjoyed this time, seriously $[\ldots]$ it is good for me to talk to a different person. Seriously. You do not imagine the meaning that this has for us. It is very good that a person can talk to an outsider, a different person, tell our story. [...] And mostly talking to a person that I feel is not judging me" [interviews, RG].

This narrative touches on how, in some cases, interviews might provide prisoners a rare opportunity to step out of their daily routines behind bars and talk "freely" about their life with someone who is not positioned as a moral judger (Liebling 1999; Jewkes and Wright 2016). Protected by confidentiality and distant from relationships with other prisoners and staff, our role as trusted outsiders thus provided prisoners an opportunity to discuss topics that are usually not voiced in prison: violent episodes among prisoners and between prisoners and staff, drug trafficking in the prison setting, suicide attempts, episodes of self-harm, circulation of tobacco and other goods, platonic romantic relations with prison guards, sexual experiences with prisoners, among other sensitive issues. The situations that characterized our fieldwork therefore show how being an outsider might be an important tool to build trust with respondents and make them more comfortable about sharing information - as in Simmel's notion of the "stranger" (Simmel 1950). This is also highlighted by 
Bucerius: "achieving status as an outsider trusted with 'inside knowledge' may provide the ethnographer with a different perspective and different data than that potentially afforded by insider status" (2013: 690), which, in turn, may have a myopic view owing to its insider commitment (Phillips and Earl 2010).

Perceiving us as trusted outsiders, prisoners sometimes attempted to benefit from our presence to mitigate the scarcity of formal support available to them. Not seldom, we noticed that prisoners would deal with us as counsellors, therapists and confidants, just as Jewkes and Wright (2016) also stated. They asked us for advice about their intimate relationships with romantic partners and children. In other situations, they also asked us to clarify their legal situation. Indeed, on one occasion, SG explained to a foreign prisoner her legal situation, since during the interview she admitted not knowing the reason that led to her arrest because of language barriers: "[While crying] I am complicit. And I do not even know what it means. [...] [I explain the definition of accomplice]. But I did not know he had drugs in the car. I have never done anything wrong" [interviews, SG].

Although maintaining some common threads among them, all interviews were different since interviewees' and researchers' characteristics interacted in unique ways. In fact, with both researchers, issues related to perceived youthfulness, gendered identity and professional status took the front stage in negotiating involvement during interviews, resulting in an intersectional understanding of the trust built between researchers and interviewed prisoners. The following episode exemplifies such intersectional character of managing distrust while interacting with prisoners. After a six-month period conducting interviews in a female prison in which similarity between the participants and the researcher was, at least, based on gender, RG started conducting interviews with male prisoners. As the following diary excerpt shows, this change implied several challenges, creating a highly stressful period for RG.

"The first interview with a male prisoner broke all my confidence. In the 15 minutes that the interview lasted I only got 'yes' and 'no' as answers and I failed to create any type of empathy with my interviewee. It was clear that he saw me as a girl who does not inspire any confidence and to whom he would not relay any information from a private domain" [fieldnotes, RG].

After this episode, it was emotionally difficult for RG to continue conducting interviews with men. It was clear for her that, due to her perceived youthfulness - here translated into notions associated with professional immaturity, ingenuousness and lack of symbolic power - she would be considered by male prisoners as a naïve young girl to whom certain kinds of private information should not be disclosed. Frustrated, and dealing with several ethical dilemmas, a few days went by when RG only went to the prison to check prisoners' files and talk with 
anyone willing to do so: professionals and prisoners with administrative job positions (bar staff, canteen and cleaning). These prisoners were essential for rebuilding her trust in her capabilities as an interviewer and tracing additional issues that could be interfering with the processes of managing distrust. In particular, these informal conversations helped RG to understand the high level of suspicion that dominated that specific prison environment. According to prisoners with whom RG developed informal conversations, the research theme she was focusing on - familial relationships - was seen as highly connected to information provided to social workers. Prisoners were therefore afraid of putting their relatives at risk by talking to her. In that particular prison, there were several stories related to the negative impact of social services on the families of prisoners and that was something most prisoners were made aware of. Therefore, the association of the role of researchers with these individuals would put the conduction of interviews at risk. As such, RG understood that, unable to overcome the implications of her perceived youthfulness into interactions with prisoners, she should benefit from emphasizing and providing proof of her dissociation not only from prison services, as she already did, but also from social services. These lessons based on the particularities of such a prison helped RG to delineate strategies that would implicitly and explicitly make clear the dissociation from criminal justice and social services. Besides spending more time with the male interviewees before the interview explaining her career path and her role as a social scientist, she also opted for a more casual dress code, such as jeans and sweaters. This helped to distance herself from the figure of the a social worker. Although seemingly minimal, RG concluded that these changes had major implications in her initial contacts with male interviewees.

As researchers we were continuously acting and reacting, moving back and forth, creating and recreating research strategies because of diverse transformations and reconfigurations in the process of conducting field research. Constantly challenged by the omnipresent question of how to build trust in a social context characterized with multiple hierarchies, in this process we emphasize the procedural, contextual and intersectional character of managing (dis)trust while interacting with prisoners. Trust appears re-enacted at each interaction, differently engaging not only with the characteristics of the field (male or female prisons) and of the participants (gender, educational level), but also with the ways in which our identity was co-constructed and perceived.

\section{FINAL REMARKS}

"Aren't you afraid [of conducting research in prisons]?" The simple answer to this is yes, we are. But not afraid of prisoners or of the prison environment. We are afraid of failing to build trust with prison staff and prisoners, afraid of failing to build rapport, afraid of failing to preserve their anonymity and 
confidentiality, and afraid of the consequences that this may have for the participants of our studies, for the research, and for us.

In this article we develop an intersectional understanding of building (dis) trust in prison settings by exposing how researchers' social position and relational dynamics in prison settings create give-and-take dynamics in the process of gaining access and building trust - the most precious but also convoluted element concerning prison qualitative research (Bucerius 2013). Our argument is that the negotiation of researchers' identities as (dis)trusted outsiders combines hybrid, intersectional and contingent elements. That is, while on the one hand, access to prison is allowed due to institutional affiliation, on the other hand, the negotiation of the researcher's position, access to prison infrastructures and the construction of (dis)trusting relationships with respondents intersect deeply with notions related to appearance, gender and professional status. Our data shows that in some cases these co-constructed identities enhance a sense of difference with respondents, thereby turning researchers into distrusted outsiders to whom scant information might be disclosed. Nevertheless, in others, these co-constructed identities enhance proximity, allowing respondents to gain a sense of trust which materializes in the access to several prison spaces and/ or to information considered confidential and/or intimate. Within the article these kinds of constantly negotiated dynamics are described as embedded in particular moments, episodes or statements of our participants that, by making clear both ours and their position in the fieldwork, generate deeper insight into the social life of prison (Rhodes 2012). Based on this, we thus aimed to outline the contingent and ever-changing nature of the researchers' position in prison and the relational dynamic of (dis)trust: from distrusted to trusted outsiders and vice-versa, in a dynamic and continuously negotiated relationship that fluctuates from the first day we enter the field up until the present day. In order to conduct ethnography in prisons we also had to engage in the process of "learning as a child" (Ingold 2014), that is, learn what really matters to people and how then to learn from them, to get intimate knowledge of actors belonging to the same society but inscribed in different (if not competing) registers. Such learning process allowed us to mitigate some of the initial strangeness of our role - as youthful academic women - and to start building relations of trust with participants that "opened up" prisons to our academic lenses.

Our article does not aim to be prescriptive but a demonstration of the several kinds of challenges researchers might face while conducting ethnographic research on prison settings. (Dis)trust issues are powerful catalysts to enable or preclude research within prisons. When researchers reflexively interrogate the role of research in different situations, they are more able to perceive the context in a dialectical manner, understand the power dynamics in the field and its features, and move forward with ethically committed research (Becker 1967; Gomes and Duarte 2018). 


\section{REFERENCES}

AEBI, Marcelo F., Mélanie M. TIAGO, and Christine BURKHARDT, 2016, SPACE I - Council of Europe Annual Penal Statistics: Prison Populations. Survey 2015. Strasbourg, Council of Europe.

BANDYOPADHYAY, Mahuya, 2006, "Competing masculinities in a prison", Men and Masculinities, 9 (2): 186-203.

BECKER, Howard S., 1967, “Whose side are we on?”, Social Problems, 14 (3): 239-247.

BECKER, Howard S., 1994, Métodos de Pesquisa em Ciências Sociais. São Paulo, Hucitec.

BEYENS, Kristel, et al., 2015, "The craft of doing qualitative research in prisons", International Journal for Crime, Justice and Social Democracy, 4 (1): 66-78.

BOURDIEU, Pierre, 2003, "Participant objectivation", Journal of the Royal Anthropological Institute, 9: 281-294.

BUCERIUS, Sandra M., 2013, "Becoming a 'trusted outsider': gender, ethnicity, and inequality in ethnographic research", Journal of Contemporary Ethnography, 42 (6): 690-721.

Clemmer, Donald, 1940, The Prison Community. New York, NY, Holt, Rinehart and Winston.

COHEN, Stanley, and Laurie TAYLOR, 1972, Psychological Survival: The Experience of Long-Term Imprisonment. Harmondsworth, Penguin.

CREWE, Ben, 2006, "Prison drug dealing and the ethnographic lens", The Howard Journal, 45: 347-368.

CREWE, Ben, 2009, The Prisoner Society: Power, Adaptation and Social Life in an English Prison. Oxford, Oxford University Press.

CREWE, Ben, 2014, "Not looking hard enough: masculinity, emotion, and prison research", Qualitative Inquiry, 20 (4): 392-403.

CUNHA, Manuela I., 1994, Malhas que a Reclusão Tece: Questões de Identidade Numa Prisão Feminina. Lisbon, Cadernos do CEJ.

CUNHA, Manuela I., 2002, Entre o Bairro e a Prisão: Tráfico e Trajectos. Lisbon, Fim de Século.

CUNHA, Manuela I., 2014a, "The ethnography of prisons and penal confinement", The Annual Review of Anthropology, 43: 217-233.

CUNHA, Manuela I., 2014b, "Etnografias da prisão: novas direções", Configurações, 13: 47-68.

DAVIES, Charlotte A., 1999, Reflexive Ethnography. London, Routledge.

DRAKE, Deborah, 2012, Prisons, Punishment and the Pursuit of Security. Basingstoke, Palgrave Macmillan.

DRAKE, Deborah, and Joel HARVEY, 2014, "Performing the role of ethnographer: processing and managing the emotional dimensions of prison research", International Journal of Social Research Methodology, 17 (5): 489-501.

DRAKE, Deborah, Rod EARLE, and Jennifer SLOAN, 2015, "General introduction: what ethnography tells us about prisons and what prisons tell us about ethnography", in D. Drake, R. Earle and J. Sloan (eds.), The Palgrave Handbook of Prison Ethnography. Basingstoke, Palgrave Macmillan, 1-16.

ELlIOTT, Jane, 2005, Using Narrative in Social Research: Qualitative and Quantitative Approaches. London, Sage Publications.

FORSEY, Martin G., 2010, "Ethnography as participant listening”, Ethnography, 11 (4): 558-572 . 
GIAllombardo, Rose, 1966, Society of Women: A Study of a Women's Prison. New York, John Wiley \& Sons.

GOMES, Sílvia, 2014, Caminhos para a Prisão: Uma Análise do Fenómeno da Criminalidade Associada a Grupos Estrangeiros e Étnicos em Portugal. Famalicão, Húmus.

GOMES, Sílvia, 2017, "Access to law and justice perceived by foreign and Roma prisoners", Race and Justice, first published online, DOI: 10.1177/2153368717699972.

GOMES, Sílvia, 2018, "How do foreign women end up in prison? An intersectional approach of criminal pathways", in S. Gomes and V. Duarte (eds.), Female Crime and Delinquency in Portugal: In and Out of the Criminal Justice System. London, Palgrave Macmillan, 75-104.

GOMeS, Sílvia, 2019, As Vozes da Prisão: Práticas e Vivências de Reinserção Social Intramuros. Famalicão, Húmus.

GOMES, Sílvia, and Vera DUARTE, 2018, "What about ethics? Developing qualitative research in confinement settings", European Journal of Criminology, first published online, DOI: $10.1177 \% 2 \mathrm{~F} 1477370818801305$.

GOMES, Sílvia, and Manuel Carlos SILVA, 2014, "Condições e trajetórias de vida de reclusos e reclusas de etnia cigana em Portugal”, Sociologia: Revista da Faculdade de Letras da Universidade do Porto, themed issue "Ciganos na Península Ibérica e Brasil: Estudos e Políticas Sociais", 77-95.

GRANJA, Rafaela, 2016, "Beyond prison walls: the experiences of prisoners' relatives and meanings associated with imprisonment", Probation Journal, 63 (3): 273-292.

GRANJA, Rafaela, 2017, Para Cá e para Lá dos Muros: Negociar Relações Familiares durante a Reclusão. Porto, Afrontamento.

GRANJA, Rafaela, 2018, "Sharing imprisonment: experiences of prisoners and family members in Portugal", in Rachel Condry and Peter Scharff Smith (eds.), Prisons, Punishment, and the Family: Towards a New Sociology of Punishment? Oxford, Oxford University Press, 258-272.

GRANJA, Rafaela, Manuela I. CUNHA, and Helena MACHADO, 2013, "Formas alternativas do exercício da parentalidade: paternidade e maternidade em contexto prisional", Ex Aequo, 28: 73-86.

GRANJA, Rafaela, Manuela I. CUNHA, and Helena MACHADO, 2014, "Mothering from prison and ideologies of intensive parenting: enacting vulnerable resistance", Journal of Family Issues, 36 (9): 1212-1232.

HEFFERNAN, Esther, 1972, Making it in Prison: The Square, the Cool, and the Life. New York, Wiley.

INGOLD, Tim, 2014, “That's enough about ethnography”, Journal of Ethnographic Theory, 4 (1): 383-395.

JACOBS, James, 1977, Stateville: The Penitentiary in Mass Society. Chicago, The University of Chicago Press.

JEWKES, Yvonne, 2012, "Autoethnography and emotion as intellectual resources: doing prison research differently", Qualitative Inquiry, 18: 63-75.

JEWKES, Yvonne, 2014, "An introduction to 'doing prison research differently' ", Qualitative Inquiry, 18 (1): 63-75.

JEWKES, Yvonne, and Serena WRIGHT, 2016, "Researching the prison", in Yvonne Jewkes, Jamie Bennett and Ben Crewe (eds.), Handbook on Prisons (Second Edition). New York, Routledge, 659-676. 
KING, Roy, 2000, "Doing research in prisons", in Roy King and Emma Wincup (eds.), Doing Research on Crime and Justice. Oxford, Oxford University Press, 285-312.

LIEBLING, Alison, 1999, "Doing research in prison: breaking the silence?", Theoretical Criminology, 3: 147-173.

LIEBLING, Alison, 2001, "Whose side are we on? Theory, practice and allegiances in prison research", British Journal of Criminology, 41: 472-484.

LIEBLING, Alison, 2014, "Postscript: integrity and emotion in prisons research", Qualitative Inquiry, 20 (4): 481-486.

NIELSEN, Malene M., 2010, "Pains and possibilities in prison on the use of emotions and positioning in ethnographic research”, Acta Sociologica, 53 (4): 307-321.

O'REILLY, Karen, 2012, "Ethnographic returning, qualitative longitudinal research and the reflexive analysis of social practice", The Sociological Review, 60 (3): 518-536.

OWEN, Barbara, 1998, In the Mix: Struggle and Survival in a Women's Prison. Albany, State University of New York Press.

PHILLIPS, Coretta, and Rod EARLE, 2010, "Reading difference differently? Identity, epistemology and prison ethnography", British Journal of Criminology, 50 (2): 360-378.

PIACENTINI, Laura, 2004, "Penal identities in Russian prison colonies". Punishment \& Society, 6 (2): $131-147$.

RHODES, Lorna A., 2004, Total Confinement: Madness and Reason in the Maximum Security Prison. Berkeley, University of California Press.

RHODES, Lorna A., 2012, "Ethnographic imagination in the field of the prison", paper presented at the "Resisting the eclipse" symposium, The Open University, Milton Keynes, UK.

ROWE, Abigail, 2014, "Situating the self in prison research: power, identity, and epistemology", Qualitative Inquiry, 20 (4): 404-416.

SIMMEL, George, 1950, The Sociology of Georg Simmel. Glencoe, Free Press.

SYKES, Gresham, 1958, Society of Captives: A Study of a Maximum Security Prison. Princeton, Princeton University Press.

TOCH, Hans, 1977, Living in Prison: The Ecology of Survival. New York, Free Press/Macmillan. WACQUANT, Loïc, 2002, "The curious eclipse of prison ethnography in the age of mass incarceration”, Ethnography, 3 (4): 37 1-397.

WALDRAM, James, 2009, "Challenges of prison ethnography", Anthropology News, 50: 4-5.

ZWERMAN, Gilda, and Gilbert GARDNER, 1986, "Obstacles to research in a state prison: regulated, segregated and under surveillance”, Qualitative Sociology, 9 (3): 293-300.

Receção da versão original / Original version

$2018 / 05 / 25$

Receção da versão revista / Revised version

$2019 / 03 / 29$

Aceitação / Accepted

$2019 / 10 / 15$

Pré-publicação online / Pre-published online

$2020 / 07 / 16$ 